\title{
FAKTOR-FAKTOR YANG MEMPENGARUHI NASABAH MENGADOPSI INTERNET BANKING
}

\author{
Ronny \\ Program Studi Manajemen \\ STIE Perbanas Surabaya \\ Jalan Nginden Semolo 34-36, Surabaya
}

\begin{abstract}
The study about adoption in internet banking by banking customer has already done by researches in Indonesia and abroad. This scientific articles is to analyse factors influence the behavior of banking customer in adopting internet banking service. The research method used was library analysis by observing research for the last five years regarding adoption of internet banking. The result of research indicated that seven variables was considered and influenced the decision of banking customer in adopting the internet banking, i.e: marketing communication, risk, security, benefit, user friendly website, trust, and banking customer experience.
\end{abstract}

\begin{abstract}
ABSTRAK
Studi tentang adopsi internet banking oleh nasabah bank sudah banyak diteliti baik penelitian dalam maupun luar negeri. Artikel ilmiah ini menganalisa faktorfaktor yang mempengaruhi perilaku nasabah mengadopsi layanan internet banking. Metode penelitian yang digunakan adalah analisis pustaka menelusuri penelitian 5 tahun terakhir mengenai adopsi internet banking. Hasil penelitian menunjukkan bahwa 7 (tujuh) variabel yang dipertimbangkan dan mempengaruhi keputusan nasabah mengadopsi internet banking, yaitu komunikasi pemasaran, resiko, keamanan, manfaat, user friendly website, kepercayaan dan pengalaman nasabah.
\end{abstract}

Keywords: internet banking, bank consumer.

\section{PENDAHULUAN}

Teknologi informasi berkembang pesat menghasilkan produk yang canggih dengan berbagai fitur yang dapat dimanfaatkan oleh pengguna individu maupun korporasi. Faktor iklim persaingan yang tinggi diantara produsen komputer, dan perkembangan pesat riset di bidang teknologi informasi yang menghasilkan karya teknologi yang kapabilitasnya tinggi dengan biaya murah mendorong konsumen untuk membeli, meng- 
gunakan, dan memperoleh manfaat penggunaan teknologi informasi.

Bank sebagai organisasi berperanan penting dalam perekonomian Indonesia. Bank berfungsi aktif memberikan layanan publik dalam sektor perbankan. Bank dituntut untuk mampu memberikan layanan publik yang maksimal misalnya transaksi keuangan berlangsung dengan mudah, cepat, dan aman. Salah satu model layanan nasabah yang diselenggarakan bank adalah layanan internet banking.

Beragam manfaat yang dapat diperoleh nasabah dengan memanfaatkan layanan internet banking diantaranya transaksi dapat berlangsung 24 jam, nasabah dapat mengakses dimana saja asalkan terhubung dengan internet. Berbagai fitur layanan tersedia seperti transfer uang, cek saldo, bayar tagihan listrik, bayar tagihan air, termasuk pembelian pulsa telepon.

Data dari Kementerian Komunikasi dan Informatika melalui situs Kominfo.go.id bahwa sampai November 2013 pengguna internet di Indonesia mencapai 63 juta orang. Data dari situs sharingvision.com bahwa transaksi internet banking di Indonesia telah mencapai Rp 3.642 triliun. Kedua data tersebut menunjukkan potensi internet banking berkembang di masa akan datang, dari segi teknologinya maupun serapannya yang tidak hanya menjadi daya tarik bagi nasabah, tapi juga daya tarik bagi bank.

Setiap nasabah memiliki alasan manfaat yang ingin diperoleh dengan mengadopsi layanan internet banking. Di sisi lain, teknologi merupakan perangkat yang memerlukan kemampuan atau keahlian untuk menggunakannya. Pada sebagian orang mungkin menjadi kendala menggunakan layanan internet banking karena penguasaan yang lemah terhadap penggunaan teknologi informasi. Sementara, kebutuhan layanan cepat juga menjadikan salah satu pertimbangan bagi nasabah.

Penting untuk meneliti faktorfaktor apa yang mendasari nasabah memutuskan untuk mengadopsi layanan internet banking agar diperoleh gambaran utuh yang bermanfaat bagi industri perbankan dalam meningkatkan layanan internet banking dengan tujuan akhir memberikan kepuasan nasabah sehingga tercipta loyalitas nasabah.

Tulisan ini merupakan hasil penelusuran beberapa penelitian tentang adopsi internet banking 5 tahun terakhir dari sudut pandang nasabah, untuk dianalisis mengenai faktor-faktor yang mempengaruhi nasabah mengadopsi internet banking.

\section{TINJAUAN PENELITIAN}

1. Clemes (2012) meneliti mengenai faktor-faktor yang berdampak pada keputusan pelanggan untuk mengadopsi fasilitas internet banking di industri perbankan di New Zealand. Penelitian ini menggunakan metode survei yang dilakukan melalui email dengan melibatkan sebanyak 1.500 responden. Dari seluruh responden yang dikirim kuesioner, responden yang mengembalikan kuesioner ada 462 responden. Metode analisis yang digunakan adalah analisis faktor dan analisis multivariate. Hasil penelitian menunjukkan bahwa variablevariabel user-friendly website, marketing communications, perceived risks, price dan internet 
access merupakan variabelvariabel yang berdampak pada keputusan konsumen untuk mengadopsi internet banking. User friendly website menunjukkan sifat website mampu untuk dipahami, dipelajari, dan digunakan oleh nasabah, karena fiturnya yang tersedia secara sederhana. Marketing communication adalah komunikasi pemasaran antara bank dan nasabahnya, diantaranya melalui brosur. Perceived risks merupakan resiko yang dipersepsikan nasabah yang berkaitan dengan keamanan dan tanggungjawab bank jika terjadi gangguan keamanan.

2. Nasri (2011) meneliti mengenai faktor-faktor yang mempengaruhi konsumen mengadopsi fasilitas internet banking di Tunisia. Penelitian menggunakan metode analisis faktor dan regresi dengan total responden 253 responden di Tunisia. Hasil penelitian menunjukkan bahwa faktor-faktor convenience, risk, security, dan internet knowledge mempengaruhi konsumen untuk mengadopsi fasilitas internet banking di Tunisia.

3. Perkins and Annan (2013) meneliti tentang faktor-faktor yang berdampak pada adopsi internet banking di Ghana. Penelitian ini menggunakan model TAM (Technology Acceptance Model) untuk menelusuri faktorfaktor yang mempengaruhi perilaku konsumen untuk menggunakan internet banking. Data dianalisis menggunakan regresi berganda. Hasil penelitian menunjukkan bahwa variabelvariabel perceived usefulness, per- ceived ease of use, government support, trust dan security merupakan variabel-variabel yang mempunyai pengaruh signifikan pada minat konsumen untuk mengadopsi online banking.

4. Eze and Manyeki (2011) melakukan penelitian yang dimaksudkan untuk menginvestigasi faktorfaktor yang mempengaruhi penggunaan layanan internet banking di antara kaum muda di Malaysia. Kerangka pemikiran dari penelitian ini bersandar pada pengembangan Technology Acceptance Model. Data yang dianalisis terdiri dari 229 responden. Hasilnya mengindikasikan bahwa variabelvariabel perceived ease of use, perceived usefulness, relative advantage, self-efficacy, perceived credibility dan trialability merupakan variabel-variabel yang berpengaruh signifikan terhadap perilaku konsumen mengadopsi internet banking.

5. Lee (2011) melakukan penelitian untuk menelusuri faktor-faktor yang mempengaruhi minat dari konsumen untuk menggunakan fasilitas online banking. Penelitian ini menggabungkan model TAM (Technology Acceptance Model) dan TPB (Theory of Planned Behavior). Penelitian ini mengeksplorasi dan mengintegrasikan berbagai keuntungan dari fasilitas online banking. Hasil penelitian menunjukkan bahwa minat pada penggunaan online banking dipengaruhi oleh variabel-variabel security/privacy risk, financial risk, perceived benefit, attitude dan perceived usefulness. 
Tabel 1

Penelitian Adopsi Internet Banking

\begin{tabular}{|c|c|c|c|}
\hline Judul Penelitian & Tahun & Analisis Data & Variabel \\
\hline $\begin{array}{l}\text { "The Factors Impacting on } \\
\text { Customers' decisions to adopt } \\
\text { Internet Banking” } \\
\text { Oleh : Michael D. Clemes et al }\end{array}$ & 2012 & Analisis Faktor & $\begin{array}{l}\text { User friendly } \\
\text { website, } \\
\text { Marketing } \\
\text { Communication, } \\
\text { perceived risks, } \\
\text { price, dan internet } \\
\text { access }\end{array}$ \\
\hline $\begin{array}{l}\text { Factors Influencing the } \\
\text { Adoption of Internet Banking in } \\
\text { Tunisia” } \\
\text { Oleh : Wadie Nasri }\end{array}$ & 2011 & $\begin{array}{l}\text { Analisis Faktor dan } \\
\text { Regresi }\end{array}$ & $\begin{array}{l}\text { Convenience, } \\
\text { Risk, Security, dan } \\
\text { Internet } \\
\text { Knowledge }\end{array}$ \\
\hline $\begin{array}{l}\text { Factors affecting the Adoption } \\
\text { of Online Banking in Ghana } \\
\text { Oleh : Ed-Zilla Daniel Perkins } \\
\text { dan Jonathan Annan }\end{array}$ & 2013 & Regresi Berganda & $\begin{array}{l}\text { Perceived } \\
\text { Usefulness, } \\
\text { Perceived Ease of } \\
\text { Use, dan } \\
\text { government } \\
\text { support, trust dan } \\
\text { security }\end{array}$ \\
\hline $\begin{array}{l}\text { Factors Affecting Internet } \\
\text { Banking Adoption among Young } \\
\text { Adults : Evidence from Malaysia } \\
\text { Oleh : Uchenna Cyril Eze dan } \\
\text { Jennifer Keru Manyeki }\end{array}$ & 2011 & Regresi & $\begin{array}{l}\text { perceived ease of } \\
\text { use, perceived } \\
\text { usefulness, } \\
\text { relative } \\
\text { advantage, self- } \\
\text { efficacy, perceived } \\
\text { credibility dan } \\
\text { trialability }\end{array}$ \\
\hline $\begin{array}{l}\text { Factors influencing the adoption } \\
\text { of internet banking: An } \\
\text { integration of TAM and TPB } \\
\text { with perceived risk and } \\
\text { perceived benefit } \\
\text { Oleh : Ming-Chi Lee }\end{array}$ & 2011 & Regresi & $\begin{array}{l}\text { security/privacy } \\
\text { risk, financial risk, } \\
\text { perceived benefit, } \\
\text { attitude dan } \\
\text { perceived } \\
\text { usefulness }\end{array}$ \\
\hline
\end{tabular}




\section{PEMBAHASAN}

Berdasarkan tinjauan penelitian tentang adopsi internet banking di beberapa negara mengarah pada beberapa faktor yang dapat dikategorikan menjadi tujuh variabel yaitu:

\section{Komunikasi Pemasaran.}

Nasabah dapat dipengaruhi oleh kegiatan komunikasi pemasaran yang disampaikan melalui brosur, atau komunikasi nasabah dengan pegawai bank yang memberikan penjelasan tentang layanan internet banking. Pegawai bank dapat menjelaskan berbagai kemudahan dan manfaat yang dapat diperoleh bila nasabah menggunakan fasilitas internet banking. Jadi promosi dari pihak perbankan mengenai berbagai keuntungan dan manfaat dari penggunaan internet banking akan sangat berpengaruh terhadap minat nasabah menggunakan fasilitas internet banking. Di samping itu nasabah juga dapat dipengaruhi oleh komunikasi dari teman dan kolega, atau melalui komunikasi dari mulut ke mulut (word-of-mouth.) (Clemes, 2012; Nasri, 2011)

\section{User Friendly Website.}

Layanan internet banking menggunakan media website sebagai antarmuka/penghubung interaksi nasabah dengan perbankan. Beberapa pertimbangan nasabah di antaranya pengorganisasian informasi dalam website, waktu respon, kejelasan informasi, tersedianya fungsi-fungsi pencarian informasi, keterkinian informasi. (Clemes, 2012). Variabel perceived ease of use dalam penelitian Perkins and Annan (2013) adalah kemudahan menggunakan internet banking dapat dimasukkan ke dalam variabel user friendly website, karena salah satu unsur user friendly website adalah kemudahan menggunakan termasuk kemudahan mempelajari cara mengoperasionalkan fasilitas yang ada di internet banking.

3. Security (Keamanan).

Layanan internet banking tidak mempertemukan antara nasabah dan pegawai bank secara langsung, tetapi bank direpresentasikan oleh website perbankan yang memungkinkan terjadinya layanan dan transaksi. Keamanan internet banking menjadi faktor yang mempengaruhi nasabah dalam mengambil keputusan untuk adopsi internet banking. Nasabah membutuhkan penjelasan tentang bentuk keamanan yang disediakan oleh perbankan. Nasabah tidak hanya mempertimbangkan proteksi keamanan internet banking, tetapi juga mempertimbangkan pola perilaku/ kebiasaan nasabah dalam mengamankan data pribadi miliknya, mengamankan penggunaan internet atau komputer seperti penggunaan password dan username (Clemes, 2012; Nasri, 2011; Lee, 2011). Faktor keamanan internet dapat bertolak belakang dengan kecepatan akses, karena semakin tinggi tingkat keamanan dapat berakibat kecepatan akses menjadi berkurang, seperti dalam kasus penggunaan antivirus.

4. Resiko.

Nasabah mempertimbangkan resiko yang dihadapi atas gangguan keamanan atau kesalahan dalam transaksi internet banking. Resiko dan keamanan merupakan faktor 
penting yang dipertimbangkan nasabah karena transaksi uang lewat internet memerlukan keamanan yang menjamin transaksi tidak diganggu oleh para pelaku kejahatan, dan bank melindungi nasabahnya untuk mencegah dan menanggulangi gangguan keamanan. Keberadaan regulasi perbankan dan perlindungan atas informasi pribadi nasabah, rendahnya resiko fraud, dan pertanggungjawaban bank jika resiko sistem elektronik perbankan diserang oleh hacker menjadi perhatian nasabah dalam mempertimbangkan untuk mengadopsi internet banking (Clemes, 2012 dan Nasri, 2011).

\section{Kepercayaan.}

Nasabah dipengaruhi oleh faktor seberapa jauh kepercayaan dirinya menggunakan layanan internet banking. Kepercayaan nasabah atas layanan internet banking menyangkut keamanan transfer uang, penyimpanan informasi pribadi secara aman, keuntungan yang diperoleh, dan kualitas informasi pada website perbankan (Perkins and Annan, 2013). Kepercayaan timbul dipengaruhi pula oleh kelompok sosial seperti rekomendasi dari keluarga atau teman sejawat. Hal ini dikarenakan internet banking adalah salah satu aplikasi teknologi informasi di bidang perbankan, sebagian nasabah menganggap internet banking memiliki faktor kerumitan tertentu untuk digunakan, sehingga terdapat nasabah yang menggantungkan keputusannya atas kepercayaannya dari rekomendasi orang lain.

\section{Manfaat.}

Beberapa manfaat yang dipertimbangkan nasabah di antaranya nasabah membandingkan kelebihan internet banking dibandingkan layanan langsung di bank seperti tidak ada antrian, hemat waktu, akses di segala waktu, kelengkapan dan kemudahan mengelola transaksi, selain itu nasabah juga mempertimbangkan biaya internet banking, faktor kemudahan komunikasi dan tingkat frustasi menggunakan internet banking (Clemes, 2012; Perkins and Annan, 2013; Eze, 2011). Nasabah juga mempertimbangkan manfaat dengan membandingkan price atau harga yang harus dibayarkan untuk mengakses internet banking yaitu harga akses internet dan biaya administrasi yang ditentukan oleh bank atas penggunaan layanan internet banking. Perbandingan antara manfaat dan pengorbanan nasabah merupakan nilai yang dirasakan oleh nasabah itu sendiri.

\section{Pengalaman.}

Pengalaman dan pengetahuan nasabah menggunakan internet turut menentukan keputusan adopsi internet banking, karena layanan internet banking berbasis teknologi. Nasabah mempertimbangkan kemampuan dirinya menggunakan komputer, internet, search engine, dan pengalaman mengakses internet banking (Clemes, 2012). Internet Access (Clemes, 2012) dan Internet Knowledge (Nasri, 2011) dapat dikategorikan ke dalam variabel pengalaman karena pengetahuan bersumber dari pengalaman dalam mengakses komputer dan internet. 


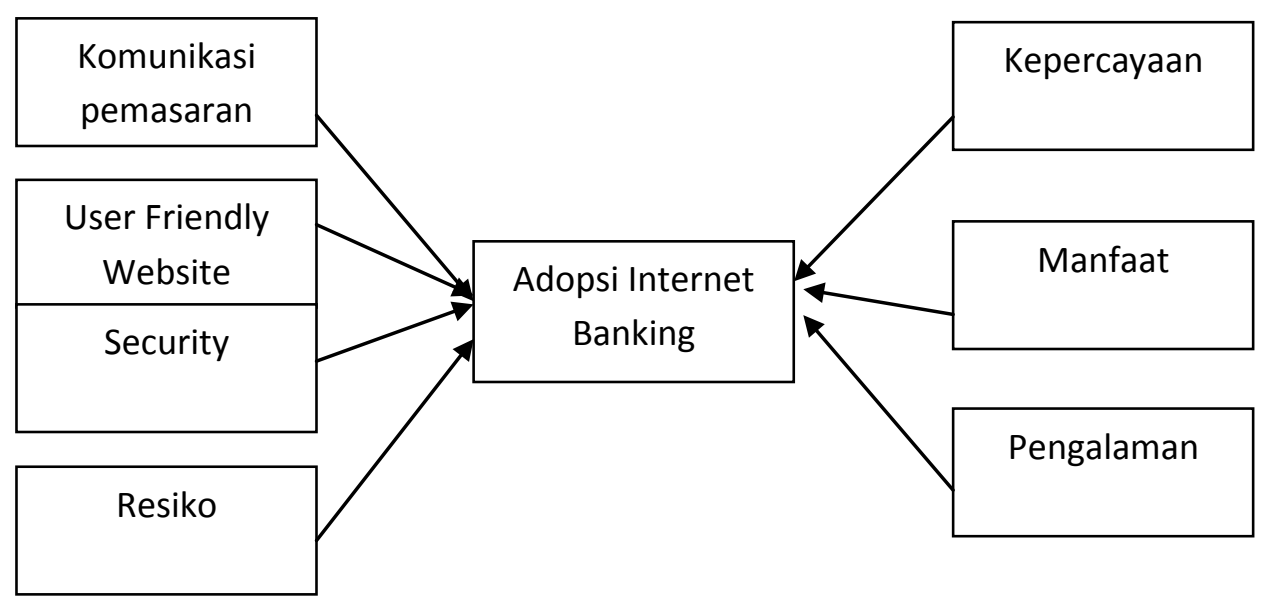

Gambar 1.

\section{Faktor yang mempengaruhi Nasabah mengadopsi Internet Banking}

\section{KESIMPULAN}

Tujuh variabel yang mempengaruhi nasabah dalam mengadopsi internet banking adalah komunikasi pemasaran, user friendly website, security, resiko, kepercayaan, manfaat, dan pengalaman. Variabel pengalaman merupakan faktor dari dalam diri nasabah atas pengalaman menggunakan internet dan komputer. Variabel kepercayaan merupakan tingkat kepercayaan nasabah atas layanan internet banking yang berhubungan pula dengan faktor security, resiko, dan manfaat yang diperoleh nasabah. Komunikasi pemasaran berkaitan dengan kemampuan bank dalam mempengaruhi dan meyakinkan nasabah untuk mau menggunakan internet banking, komunikasi ini berhubungan erat dengan kemampuan pegawai bank menjelaskan kepada nasabah tentang perlindungan keamanan, peluang resiko, dan manfaat layanan internet banking.

Implikasi praktis dari penelitian bidang adopsi internet banking penting bagi dunia perbankan, bahwa bank sebagai penyelenggara internet banking tidak hanya mengedepankan kekuatan layanan dari segi kelengkapan fitur layanan saja, tetapi juga harus membangun komunikasi promosi dengan pihak nasabah, meningkatkan aspek keamanan, ada jaminan terhadap resiko yang dapat muncul, dan tetap meningkatkan kemampuan nasabah untuk mudah dalam mempelajari dan menggunakan website perbankan.

\section{SARAN}

Penelitian ini masih dapat dilanjutkan dengan penelitian empiris untuk menguji dan menganalisis ketujuh variabel yang mempengaruhi adopsi internet banking untuk kasus di Indonesia.

Selain penelitian di bidang adopsi internet banking dari perspektif nasabah sebagai unit analisis, masih dapat dilanjutkan penelitian berikutnya dari perspektif penyelenggaraan internet banking untuk memahami strategi bank menyelenggarakan layanan internet banking. 
Penelitian selanjutnya perlu dianalisis faktor-faktor apa yang mempengaruhi kepuasan dan loyalitas nasabah dan bagaimana dampaknya terhadap pengembangan strategi layanan internet banking di masa akan datang dengan analisis peluang, ancaman, tantangan, dan kelemahan dalam penyelenggaraan layanan internet banking.

\section{DAFTAR KEPUSTAKAAN}

Clemes, Michael D., 2012, The Factors Impacting on Customers' Decisions to adopt Internet Banking, Journal of Bank and Bank System, Vol. 7, No. 12, page 33.

Eze, Uchenna Cyril and Jennifer Keru Manyeki, 2011, Factors Affecting Internet Banking Adoption among Young Adults: Evidence from Malaysia, International Conference on Social Science and Humanity, IPEDR, Vol. 5, IACSIT Press, Singapore. 2011, page 377.

Lee, Ming-Chi Lee, 2011, Factor Influencing The Adoption of Internet Banking: An Integration of TAM and TPB with Perceived Risk and Perceived Benefit, Elsevier Journal, page 294.
Nasri, Wadie, 2011, Factors Influencing the Adoption of Internet Banking in Tunisia, International Journal of Business and Management, published by Canadian Center of Science and Education, Vol. 6, No. 8, August 2011, page 143.

Perkins, Ed-Zilla Daniel and Jonathan Annan, 2013, Factors Affecting The Adoption of Online Banking in Ghana, International Journal of Business and Social Research, Vol. 3, No. 6, Juni 2013, page 94. 